\title{
Pertumbuhan dan Hasil Tanaman Kacang Tanah terhadap Pemberian Air Cucian Beras Coklat di Lahan Rawa Lebak
}

\author{
(The Growth and Yield of Peanuts to Giving of Brown Rice \\ Washing Water at Lebak Wetland)
}

\author{
Ahmad Riyadi ${ }^{1)}$ dan Nurul Istiqomah ${ }^{2)}$ \\ Program Studi Agroteknologi, Sekolah Tinggi Ilmu Pertanian \\ ${ }^{1)}$ riyadiahmad@gmail.com \\ 2)email: qoqom_81@yahoo.co.id
}

\begin{abstract}
ABSTRAK
Kacang tanah merupakan salah satu jenis tanaman palawija yang menduduki urutan ketiga setelah jagung dan kedelai. Kacang tanah telah lama dimanfaatkan sebagai bahan pangan, sementara itu produk sampingannya dapat dimanfaatkan sebagai pakan ternak. Sehubungan dengan masalah kurangnya kesuburan pada tanah rawa lebak, agar menghasilkan produksi yang tinggi dengan kualitas yang baik, maka perlu dilakukan usaha untuk menambahkan unsur hara. Air cucian beras mempunyai kandungan karbohidrat yang tinggi. Karbohidrat bisa jadi perantara terbentuknya hormon auksin dan giberelin. Dua jenis bahan yang banyak digunakan dalam zat perangsang tumbuh (ZPT) buatan. Penelitian ini bertujuan (i) untuk mengetahui respon pertumbuhan dan hasil tanaman kacang tanah terhadap pemberian air cucian beras coklat pada lahan rawa lebak, (ii) untuk mengetahui interval waktu terbaik pemberian air cucian beras coklat terhadap pertumbuhan dan hasil tanaman kacang tanah pada lahan rawa lebak. Penelitian ini dilaksanakan di Desa Banyu Tajun Pangkalan Kecamatan Sungai Pandan Kabupaten Hulu Sungai Utara dari bulan April sampai Juni 2013, menggunakan Rancangan Acak Lengkap (RAL) faktor tunggal. Faktor yang diteliti adalah interval pemberian air cucian beras coklat. Hasil penelitian menunjukkan bahwa perlakuan tidak berpengaruh terhadap peubah pengamatan tinggi tanaman dan jumlah cabang, dan berpengaruh sangat nyata terhadap peubah pengamatan jumlah polong pertanaman, bobot basah polong pertanaman, dan bobot kering polong pertanaman. Hasil penelitian ini menunjukkan bahwa perlakuan terbaik adalah pada $p_{5}$ (6 hari).
\end{abstract}

Kata kunci: Kacang tanah, air cucian beras, beras coklat, rawa lebak.

\begin{abstract}
Peanuts is one type of secondary crop which ranks third after corn and soybeans. Peanuts have long been used as food, while by-products can be used as animal feed. In connection with the problem of lack of fertility in lebak wetland soil, in order to produce high production with good quality, efforts need to be made to add nutrients. Rice washing water has a high carbohydrate content. Carbohydrates can be an intermediary for the formation of the hormones auxin and giberelin. Two types of ingredients that are widely used in artificial growth stimulants. This study aims (i) to determine the growth response and yield of peanut plants to the provision of brown rice washing water on lebak wetland, (ii) to find out the best time interval for brown rice washing water for plant growth and yield peanuts on lebak wetland. This research was conducted in Banyu Tajun Pangkalan Village, Sungai Pandan Sub-District, Hulu Sungai Utara Regency from April to June 2013, using randomized complete design (CRD) with single factor. The factors studied were the brown rice washing water interval. The results showed that the treatment did not affect the observation of plant height and number of branches, and had a very significant effect on the variables observed in the number of crop pods, wet weight of crop pods, and dry weight of plant pods. The results of this study indicate that the best treatment is at $p_{5}$ (6 days).
\end{abstract}

Keywords: Peanuts, rice washing water, brown rice, lebak wetland.

\section{PENDAHULUAN}

Lahan rawa lebak memiliki potensi dan prospek besar untuk di manfaatkan sebagai areal produksi pertanian, khususnya padi dan merupakan salah satu pilihan strategis bagi peningkatan produksi pangan nasional dan dapat dijadikan sebagai lahan abadi untuk mempertahankan produksi 
pangan nasional. Petani lokal lebak lahan rawa lebak, sejak lama dan sudah lebih dari ratusan tahun memanfaatkan lahan rawa untuk bercocok tanam padi, palawija dan berbagai jenis tanaman hortikultura (Rafieq, 2004), salah satunya adalah kacang tanah. Kacang tanah (Arachis hipogaea. L.) merupakan salah satu jenis tanaman palawija yang menduduki urutan ketiga setelah jagung dan kedelai. Kacang tanah telah lama dimanfaatkan sebagai bahan pangan, sementara itu produk sampingannya dapat dimanfaatkan sebagai pakan ternak (Suprapto, 2005).

Hal yang menjadi permasalahan pada lahan rawa lebak adalah sifat kimia yaitu rendahnya ketersediaan unsur hara N, P dan K. Sifat fisik tanah yang kurang menguntungkan karena rawa lebak memiliki tekstur liat, tidak gambur dan pori tanah yang sangat kecil sehingga mikroorganisme sulit untuk hidup (Noor, 2004). Sehubungan dengan masalah kurangnya kesuburan pada tanah rawa lebak, agar menghasilkan produksi yang tinggi dengan kualitas yang baik, maka perlu dilakukan usaha untuk menambahkan unsur hara. Pemupukan merupakan satu-satunya cara yang dapat dilakukan untuk memenuhi ketersedian unsur hara tanah yang dibutuhkan tanaman. Dengan adanya pemupukan, tanaman dapat tumbuh optimal dan berproduksi maksimal (Redaksi Agromedia, 2007).

Air cucian beras selain mengandung bahan organik sebagai sumber unsur hara, juga mempunyai kandungan karbohidrat yang tinggi. Karbohidrat bisa jadi perantara terbentuknya hormon auksin dan giberelin. Dua jenis bahan yang banyak digunakan dalam zat perangsang tumbuh (ZPT) buatan. Auksin bermanfaat merangsang pertumbuhan pucuk dan kemunculan tunas baru sedangkan giberelin berguna untuk merangsang pertumbuhan akar (Leandro, 2009).

Unsur hara dalam tanah tidak selalu tersedia langsung untuk tanaman. Sehingga perlu proses dalam penyediaan unsur hara tersebut. Interval waktu pemberian air cucian beras coklat dapat mempengaruhi proses dekomposisi unsur hara dalam tanah. Hasil penelitian Asma (2010), bahwa konsentrasi air cucian beras coklat memperlihatkan pengaruh yang sangat nyata pada tinggi tanaman dan jumlah daun tanaman seledri dengan konsentrasi $75 \%$ air cucian beras coklat dan diberikan setiap hari.

Penelitian ini bertujuan untuk (i) mengetahui respon pertumbuhan dan hasil tanaman kacang tanah terhadap pemberian air cucian beras coklat pada lahan rawa lebak, dan (ii) mendapatkan interval waktu terbaik pemberian air cucian beras coklat terhadap pertumbuhan dan hasil tanaman kacang tanah pada tanah rawa lebak.

\section{METODE PENELITIAN}

Percobaan ini dilaksanakan di Desa Banyu Tajun Pangkalan Kecamatan Sungai Pandan Kabupaten Hulu Sungai Utara dari bulan April sampai Juli 2013. Bahan yang digunakan adalah air cucian beras, benih kacang tanah Varietas Kelinci, pestisida, kayu dan paku, sedangkan alat yang dipakai adalah cangkul, alat tulis, gembor, palu, handsprayer, meteran, dan kamera.

Penelitian ini menggunakan Rancanagn Acak Lengkap (RAL) faktor tunggal. Perlakuan yang dicobakan adalah interval waktu pemberian air cucian beras coklat $(\mathrm{P})$ sebanyak 6 taraf yaitu $\mathrm{p}_{0}=$ setiap hari, $\mathrm{p}_{1}=$ setiap 2 hari, $\mathrm{p}_{2}=$ setiap 3 hari, $\mathrm{p}_{3}=$ setiap 4 hari, $\mathrm{p}_{4}=$ setiap 5 hari, dan $\mathrm{p}_{5}=$ setiap 6 hari. Dilakukan 3 kali ulangan sehingga didapatkan 18 satuan percobaan.

Peubah yang diamati adalah tinggi tanaman, jumlah cabang, jumlah polong pertanaman, berat basah polong pertanaman, dan berat kering polong pertanaman. Data yang didapat dianalisis menggunakan uji $\mathrm{F}$ pada taraf nyata $1 \%$ dan $5 \%$, kemudian diuji beda nilai tengahnya dengan uji DMRT pada taraf $5 \%$.

\section{HASIL DAN PEMBAHASAN}

\section{Vegetatif}

Peubah vegetatif yang diamati adalah tinggi tanaman dan jumlah cabang Berdasarkan hasil analisis ragam menunjukkan bahwa perlakuan pemberian air cucian beras coklat tidak berpengaruh 
terhadap pengamatan tinggi dan jumlah cabang tanaman kacang tanah. Grafik hubungan tinggi tanaman dan jumlah cabag terhadap pemberian air cucian beras coklat dapat dilihat pada Gambar 1 dan 2.

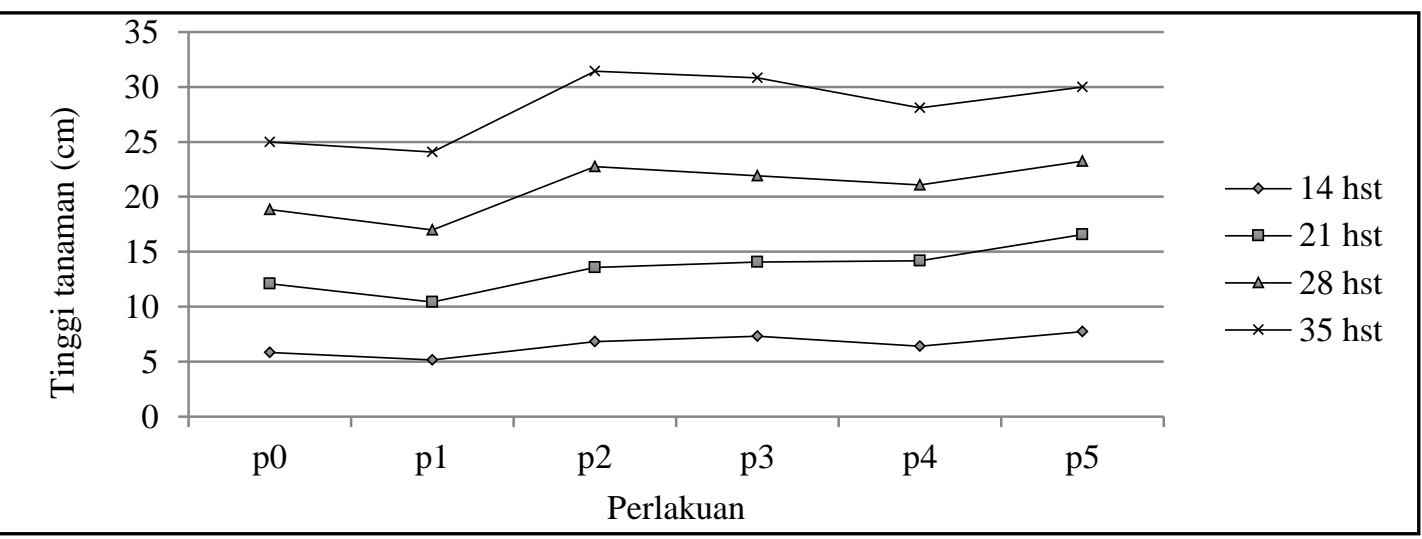

Gambar 1. Grafik hubungan tinggi tanaman kacang tanah dengan pemberian air cucian beras coklat

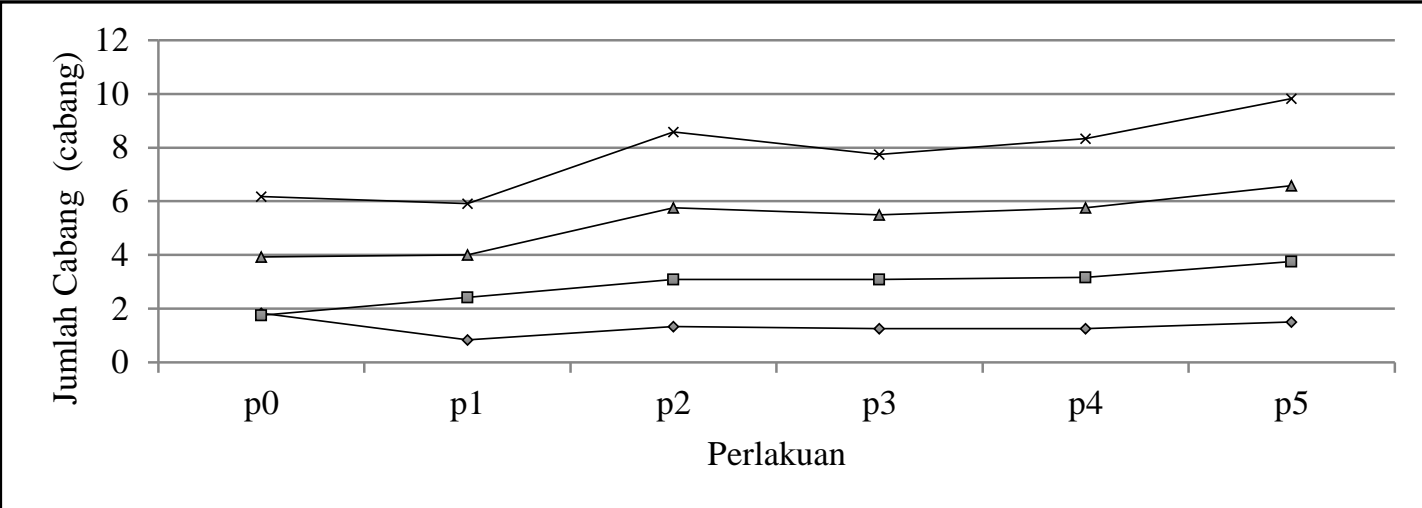

Gambar 2. Grafik hubungan jumlah cabang tanaman kacang tanah dengan pemberian air cucian beras coklat

Berdasarkan grafik di atas dapat dilihat bahwa peningkatan interval pemberian air cucian beras coklat mampu meningkatkan tinggi dan jumlah cabang tanaman kacang tanah, dengan tinggi tanaman tertinggi pada perlakuan $\mathrm{p}_{2}$ dan jumlah cabang terbanyak pada perlakuan $\mathrm{p}_{5}$.

Hasil analisis laboratorium, tanah ditempat penelitian mengandung unsur $\mathrm{N}$ yang sangat rendah yaitu $0,17 \%$ (Balittra, 2012), sedangkan air cucian beras tidak mengandung unsur N. Rendahnya kandungan unsur hara ini menyebabkan tanaman kekurangan unsur $\mathrm{N}$.

Senyawa nitrogen digunakan tanaman untuk membentuk asam amino yang akan diubah menjadi protein. Selain itu, juga dibutuhkan untuk membentuk senyawa penting seperti klorofil, asam nukleat, dan enzim. Oleh karena itu, nitrogen dibutuhkan dalam jumlah besar pada setiap tahap pertumbuhan tanaman, khususnya pada tahap pertumbuhan vegetatif, seperti pembentukan tunas, pembentukan batang termasuk percabangan, dan perkembangan daun (Novizan, 2002).

Kekurangan unsur $\mathrm{N}$ dalam tanah ini menyebabkan bintil akar tanaman kacang tanah hanya mengikat $\mathrm{N}$ yang ada diudara. Menurut Rambey (2010), keasaman tanah, kandungan hara, fotosintesis, dan iklim mempengaruhi pembentukan bintil akar. Selanjutnya menurut Novizan (2002), pada tanah yang ber-pH rendah (asam) fosfor akan bereaksi dengan ion besi dan aluminium. Reaksi ini membentuk besi fosfat atau 
aluminium fosfat yang sukar larut didalam air sehingga tidak dapat digunakan tanaman. Engelstad (1997), menyebutkan unsur K pada tanah masam ini terdapat lebih banyak dibanding pada tanah netral.

Air cucian beras dapat berfungsi sebagai zat pengatur tumbuh karena karbohidrat yang ada dalam kandungan air cucian beras ini menjadi perantara terbentuknya hormon auksin dan giberelin. Auksin bermanfaat merangsang pertumbuhan pucuk dan kemunculan tunas baru, sedangkan giberelin berguna untuk perangsangan akar (Leandro, 2009). Menurut Salisbury dan Ross (1995) dalam Wulandari, et. al. (2013), auksin juga dapat memacu kerja sitokinin dalam menginduksi enzim-enzim yang berfungsi dalam pembelahan sel terutama pada primordia daun. Dalam penelitian ini diduga hormon auksin tidak mencukupi kebutuhan tanaman kacang tanah untuk mendorong pembelahan sel yang menyebabkan munculnya tunas. Sehingga perlakuan yang diberikan tidak mampu meningkatkan pertumbuhan tanaman secara signifikan.

\section{Generatif}

Peubah generatif yang diamati adalah jumlah polong pertanaman, berat basah, dan berat kering biji kacang tanah. Berdasarkan hasil analisis ragam menunjukkan bahwa perlakuan pemberian air cucian beras coklat berpengaruh sangat nyata terhadap semua peubah pengamatan generative tanaman. Hasil uji beda rata-rata disajikan ada Tabel 1, 2 , dan 3 .

Tabel 1. Hasil uji beda rata-rata jumlah polong pertanaman kacang tanah

\begin{tabular}{cc}
\hline Pemberian air cucian beras $(\mathrm{P})$ & Rata-rata jumlah polong pertanaman (polong) \\
\hline $\mathrm{p}_{0}$ & $12,17^{\mathrm{a}}$ \\
$\mathrm{p}_{1}$ & $12,17^{\mathrm{a}}$ \\
$\mathrm{p}_{2}$ & $15,08^{\mathrm{a}}$ \\
$\mathrm{p}_{3}$ & $20,42^{\mathrm{b}}$ \\
$\mathrm{p}_{4}$ & $25,67^{\mathrm{c}}$ \\
$\mathrm{p}_{5}$ & $28,17^{\mathrm{c}}$ \\
\hline
\end{tabular}

Keterangan : Nilai rata-rata yang diikuti huruf yang berbeda menunjukkan perlakuan tersebut berbeda nyata berdasarkan uji DMRT pada taraf nyata $5 \%$

Dari Tabel 5 terlihat bahwa perlakuan $\mathrm{p}_{5}$ menunjukkan rata-rata jumlah polong pertanaman kacang tanah terbanyak yaitu
28,17 polong yang tidak berbeda nyata dengan perlakuan $\mathrm{p}_{4}$, tetapi berbeda nyata dengan perlakuan $\mathrm{p}_{0}, \mathrm{p}_{1}, \mathrm{p}_{2}$, dan $\mathrm{p}_{3}$.

Tabel 2. Hasil uji beda rata-rata bobot basah polong pertanaman kacang tanah

\begin{tabular}{cc}
\hline Pemberian air cucian beras $(\mathrm{P})$ & Rata-rata bobot basah polong pertanaman $(\mathrm{g})$ \\
\hline $\mathrm{p}_{0}$ & $17,41^{\mathrm{a}}$ \\
$\mathrm{p}_{1}$ & $20,41^{\mathrm{a}}$ \\
$\mathrm{p}_{2}$ & $25,84^{\mathrm{b}}$ \\
$\mathrm{p}_{3}$ & $30,90^{\mathrm{c}}$ \\
$\mathrm{p}_{4}$ & $33,89^{\mathrm{cd}}$ \\
$\mathrm{p}_{5}$ & $38,04^{\mathrm{d}}$ \\
\hline
\end{tabular}

Keterangan: Nilai rata-rata yang diikuti huruf yang berbeda menunjukkan perlakuan tersebut berbeda nyata berdasarkan uji DMRT pada taraf nyata $5 \%$

Dari Tabel 2 terlihat bahwa perlakuan $\mathrm{p}_{5}$ menunjukkan rata-rata bobot basah polong pertanaman kacang tanah terbanyak yaitu
$38,04 \mathrm{~g}$ yang tidak berbeda nyata dengan perlakuan $\mathrm{p}_{4}$, tetapi berbeda nyata dengan perlakuan $\mathrm{p}_{0}, \mathrm{p}_{1}, \mathrm{p}_{2}$, dan $\mathrm{p}_{3}$.

Tabel 3. Hasil uji beda rata-rata bobot kering polong pertanaman kacang tanah 


\begin{tabular}{cc}
\hline Ahmad Riyadi dan Nurul Istiqomah, Pertumbuhan dan hasil tanaman kacang... \\
\hline & \\
\hline Pemberian air cucian beras $(\mathrm{P})$ & Rata-rata bobot kering polong pertanaman $(\mathrm{g})$ \\
\hline $\mathrm{p}_{0}$ & $12,33^{\mathrm{a}}$ \\
$\mathrm{p}_{1}$ & $16,05^{\mathrm{ab}}$ \\
$\mathrm{p}_{2}$ & $20,80^{\mathrm{bc}}$ \\
$\mathrm{p}_{3}$ & $25,91^{\mathrm{cd}}$ \\
$\mathrm{p}_{4}$ & $29,30^{\mathrm{de}}$ \\
$\mathrm{p}_{5}$ & $34,55^{\mathrm{e}}$ \\
\hline
\end{tabular}

Keterangan : Nilai rata-rata yang diikuti huruf yang berbeda menunjukkan perlakuan tersebut berbeda nyata berdasarkan uji DMRT pada taraf nyata $5 \%$

Dari Tabel 3 terlihat bahwa perlakuan $\mathrm{p}_{5}$ menunjukkan rata-rata bobot kering polong pertanaman kacang tanah terbanyak yaitu $38,04 \mathrm{~g}$ yang tidak berbeda nyata dengan perlakuan $\mathrm{p}_{4}$, tetapi berbeda nyata dengan perlakuan $\mathrm{p}_{0}, \mathrm{p}_{1}, \mathrm{p}_{2}$, dan $\mathrm{p}_{3}$.

Fase generatif tanaman kacang tanah dimulai sejak timbulnya bunga sampai dengan polong masak. Fase generatif ini meliputi pembungaan, pembentukan polong, pembentukan biji, dan pemasakan biji (Sya'bani, 2012). Hasil analisis ragam menunjukkan bahwa perlakuan pemberian air cucian beras coklat berpengaruh sangat nyata terhadap semua variabel hasil yang diamati. Hal ini disebabkan tercukupinya unsur hara yang paling penting dalam fase reproduksi.

Perlakuan interval pemberian yang terbaik adalah p5 yaitu setiap 6 hari. Itu dikarenakan proses dekomposisi yang lebih baik, proses dekomposisi merupakan penguraian bahan organik oleh mikroorganisme, dalam proses ini terjadi proses mineralisasi dan immobilisasi unsur hara. Menurut Ariyanto (2009) ikatan antara organik, khususnya berupa asam-asam humat dan fulvat dengan logam disebut khelasi atau khelat. Dampak dari ikatan senyawa logam dengan senyawa organik tanah akan mengurangi ikatan fosfat oleh oksida maupun lempung silikat sehingga $\mathrm{P}$ menjadi lebih tersedia. Hal ini sesuai dengan penelitian Minardi (2006) dalam Ariyanto (2009) yang menyatakan bahwa asam humat dan asam fulvat mempunyai peran dalam pelepasan $\mathrm{P}$ yang terjerap dalam tanah serta akan meningkatkan ketersediaan $\mathrm{P}$ dalam tanah.

Semakin lama interval waktu pemberian air cucian beras coklat memberikan pengaruh yang lebih baik untuk tanaman kacang tanah. Menurut hasil analisis Laboratorium Tanah, Tanaman dan Air Balitra (2010), air cucian beras yang digunakan mengandung $\mathrm{pH}$ yang masam. Perlakuan dengan interval waktu yang lebih lama menyebabkan tanaman kacang tanah tidak sering menerima air cucian beras coklat yang mengandung $\mathrm{pH}$ masam tersebut. Sehingga lebih banyak unsur $\mathrm{P}$ tersedia yang dapat diserap tanaman. $\mathrm{pH}$ masam yang berasal dari air cucian beras coklat ini mempengaruhi dekomposisi bahan organik dalam tanah. Menurut Adrianto (2009), pada tanah dengan $\mathrm{pH}$ masam maka proses dekomposisinya menjadi lambat. Hal ini juga bisa menyebabkan unsur hara dalam tanah seperti $\mathrm{P}$ menjadi terikat oleh ion logam.

Menurut Engelstad (1997), pada tanahtanah yang sangat masam, pertukaran kation $\mathrm{K}^{+}$oleh $\mathrm{Al}_{3}{ }^{+}$dapat terjadi pada tingkat yang lebih besar dari pada dengan $\mathrm{Ca}_{2}{ }^{+}$. Karena $\mathrm{Al}$ yang dijumpai pada tanah-tanah sangat masam banyak berbentuk trivalent dan merupakan kation yang dapat dipertukarkan, ia dapat lebih mudah menukar $\mathrm{K}_{2}{ }^{+}$dari pada $\mathrm{Ca}_{2}{ }^{+}$divalen. Sebagai akibatnya, akan terdapat lebih banyak $\mathrm{K}^{+}$dalam larutan tanah-tanah sangat masam dari pada dalam tanah-tanah netral dan berkapur.

Menurut Rosmarkam dan Yuwono (2002), pemberian banyak Na pada tanaman berpengaruh terhadap kualitas produksi, baik bersifat positif maupun negatif. Pengaruh $\mathrm{Na}$ yang baik pada pertumbuhan tanaman bila kadar K relatif rendah. Pada konsentrasi K yang rendah, pemberian $\mathrm{Na}$ menaikkan produksi cukup tinggi, sedangkan pada konsentrasi $\mathrm{K}$ yang tinggi, pemberian $\mathrm{Na}$ sedikit menurunkan produksi. Dengan banyaknya kandungan $\mathrm{K}$ dalam tanah, maka 
semakin sering memberikan air cucian beras coklat berpengaruh buruk bagi tanaman kacang tanah, karena pemberian $\mathrm{Na}$ pada konsentrasi $\mathrm{K}$ yang tinggi ini menurunkan produksi tanaman. Sebaliknya, pemberian air cucian beras coklat dengan interval waktu lebih lama menyebabkan tanah tidak terlalu masam, sehingga konsentrasi $\mathrm{K}$ lebih rendah. Dengan demikian, unsur $\mathrm{Na}$ dari pemberian air cucian beras coklat mampu menaikkan produksi produksi tanaman. Hal inilah yang menyebabkan bobot kering polong pertanaman pada perlakuan $\mathrm{p}_{5}$ lebih berat dibanding pada perlakuan $\mathrm{p}_{0}, \mathrm{p}_{1}, \mathrm{p}_{2}, \mathrm{p}_{3}$, dan $\mathrm{p}_{4}$.

\section{KESIMPULAN}

Terdapat respon hasil tanaman kacang tanah terhadap pemberian air cucian beras coklat pada lahan rawa lebak, dengan interval waktu pemberian air cucian beras coklat yang memperlihatkan respon hasil terbaik bagi tanaman kacang tanah pada lahan rawa lebak adalah 6 hari $\left(\mathrm{p}_{5}\right)$.

\section{DAFTAR PUSTAKA}

Adrianto, J. 2009. Proses Mineralisasi N Organik Menjadi $N$ Tanah serta Reaksinya. http://jokoadrianto.blogspot.com.

Ariyanto, D.P. 2009. Ikatan Antara Asam Organik Tanah Dengan Logam. http://ariyanto.staff.uns.ac.id.

Diakses tanggal 14 September 2013.

Asma, R. 2010. Pengaruh pemberian air cucian beras coklat terhadap pertumbuhan dan hasil tanaman seledri (Apium graveolens L.) pada lahan rawa lebak. Skripsi. STIPER Amuntai. Amuntai.

Balittra. 2012. Hasil Analisis Contoh Tanah. Banjarbaru

Engelstad, O. P. 1997. Teknologi dan Penggunaan Pupuk. Gadjah Mada University Press. Yogyakarta.
Leandro, M. 2009. Pengaruh kombinasi air cucian beras terhadap pertumbuhan tanaman tomat dan terong. http://cikciko.blogspot.com.

Diakses tanggal 01 Februari 2012.

Noor, M. 2007. Lebak; Ekologi, Pemanfaatan dan Pengembangannya. PT. Raja Grafindo Persada. Jakarta.

Novizan. 2002. Petunjuk Pemupukan Efektif. Agromedia. Jakarta.

Rafieq, A. 2004. Sosial Budaya dan Teknologi Kearifan Lokal Masyarakat dalam Pengembangan Pertanian Lahan Lebak di Kalimantan Selatan. Banjarbaru: Balai Pengkajian dan Pengembangan Teknologi Pertanian Kalimantan Selatan.

Rambey, R. 2010. Mekanisme Infeksi Bakteri Rhizobium pada Akar Tanaman.

http://ridahati.blogspot.com.

Diakses tanggal 14 September 2013.

Redaksi Agromedia, 2007. Petunjuk Pemupukan, Cetakan I, PT. AgroMedia Pustaka. Jakarta.

Rosmarkam, A. dan Yuwono, N.W. 2002. Ilmu Kesuburan Tanah. Kanisius. Yogyakarta.

Suprapto. 2005. Bertanam Kacang Tanah. Penebar Swadaya. Jakarta.

Sya'bani, N.R. 2012. Pengaruh paclobutrazol terhadap karakteristik fisiologis dan hasil kacang tanah (Arachis hypogaea L.) Varietas Sima dan Kelinci. http://repository.ipb.ac.id. Diakses tanggal 14 September 2013.

Wulandari, R.C., Linda, R., dan Mukarlina. 2013. Pertumbuhan stek melati putih (Jasmine sambac (L) W. Ait) dengan pemberian air kelapa dan 
IBA (Indole Butyric Acid). J.

Protobion. Vol 2 (2). 